Map by Rennie Bere showing how the area available to elephants south of the Nile in Uganda has shrunk between 1930 and 1872 The arrows show thelr former regular migration which is now Impossible.

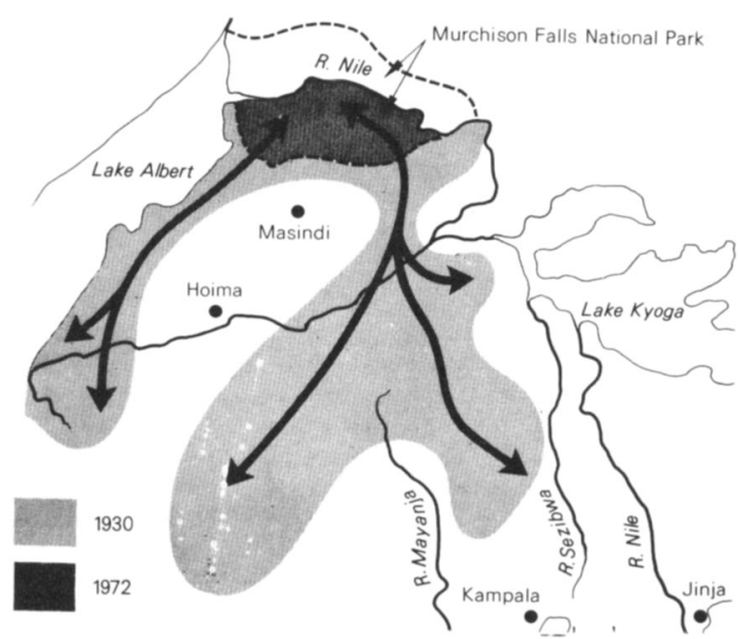

Mammals of East and Central Africa by Rennie Bere (Longman, 75p) is a survey of the mammals in their wild habitats, arranged according to their feeding habits herbivores, insect-eaters, omnivores, and carnivores. Every order and every family in the region is covered in $\mathbf{7 3}$ pages, ranging from elephants and lions to bats and shrews, with numerous illustrations, either black and white photographs or his own line drawings. The method highlights some of the conservation problems, as the author's graphic map, reproduced here, of the elephant problem in Uganda shows. A map of the region marks all the national parks and game reserves and there is a systematic list of the orders and families.

\title{
Water Plants of the World, by C. D. K. Cook et al. Dr W. Junk, D. Glds. 120.
}

Every genus of plants that normally spends at least two months of the year submerged in, or floating on freshwater is covered in this invaluable manual for all working on aquatic habitats, particularly in tropical regions and areas where good Floras are hard to come by. Many individual species are mentioned but, except for monotypic genera, specific descriptions are not given. The book is well illustrated with clear and attractive line drawings and has a valuable key to genera based on vegetative characters, an almost essential aid to the identification of most aquatic plants. Brief comments are made on ecology and any economic importance, and references given where appropriate to more detailed descriptions of the genera. This is not just a book for botanists, but for anyone who needs to name water plants, for whatever reason.

ALASTAIR H. FITTER

\section{BOOKS ON BIRDS BOUGHT AND SOLD}

An extensive collection of ornithological material is available at all times for research, reference and investment.

\section{CATALOGUES ISSUED}

Bird books are purchased either as single items, small collections or complete libraries. Please offer any that are surplus to your requirements.

\section{DAVID EVANS}

THE WHITE COTTAGE, PITT, NEAR WINCHESTER HAMPSHIRE, U.K. Telephone Winchester (0962) 3746 


\section{A Murmuration of Birds}

Desmond Nethersole-Thompson adds to his reputation as our finest bird monographer with a fourth study to add to the greenshank, the dotterel and the snow bunting: Pine Crossbills (Poyser, f5), his name for the Scottish crossbill. As usual it is based on a lifetime of intensive field observation and makes fascinating reading. There are sixteen black and white photographic plates and a splendid painting in colour by George Lodge.

Birds of Town and Suburb (Collins, £3.50) is largely based on the fruits of Eric Simms's 24-year residence in the suburbs of north-west London, but he also ranges widely over other towns and suburbs in the British Isles to make an important study of this habitat which is so vital for birds in the modern world. The book is well illustrated in both colour and monochrome by nine leading bird photographers.

The Buzzard (David \& Charles, $£ 4.75$ ) is a fine monograph by Colin $\mathbf{R}$. Tubbs, the Nature Conservancy's New Forest expert, on Britain's largest common bird of prey. It is based on many years study in the field. Another excellent monograph on a British bird, Peter M. Driver's In Search of the Eider (Saturn, £3.75) is based on the author's field work during two expeditions to the Canadian Arctic and goes into behaviour problems in some detail.

A Field Guide to the Nests, Eggs and Nestlings of British and European Birds, by Colin Harrison, is a new Collins field guide at $\mathfrak{£} 3.50$, which covers much ground not included in any other field guide, and will surely remain a standard work for many years. Philip Burton painted the attractive nestling plates.

Malcolm Ogilvie's Ducks of Britain and Europe (Poyser, $\mathfrak{£} 5$ ) is a useful summary of knowledge, admirably illustrated by the author's wife. In a nice reversal of the usual practice, the flight pictures are in colour and the static in black and white.

The RSPB Guide to British Birds (Hamlyn, $£ 1.50$ ), by David Saunders, describes and illustrates the 218 commonest British birds, including such uncommon species as the golden eagle and the red kite and even the osprey and the snowy owl (the RSPB could hardly leave those out!). The neat colour and monochrome pictures are by Noel Cusa.

The Birdwatchers' Puzzle Book, by Tim Sharrock, with decorations by Robert Gillmor, will occupy many an odd half hour, and can be had from the author, 59 Curlew Crescent (how did he manage that address?), Bedford, for 95p.

\section{RICHARD FITTER}

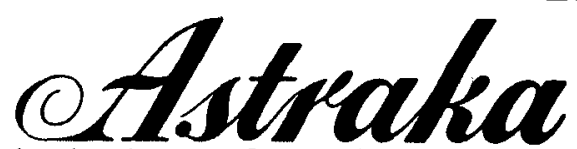

A wrap coat in simulation of Somali leopard from the Astraka Wildlife Collection of replicas of skins of rare animals that are rapidly becoming extinct. Send for details to: Dept. 2, Astraka Ltd., 1st Floor, Kent House, Market Place, London W1N 8HU Fabric by Tyber 


\section{East African Wildlife Journal}

Edited by J. B. Sale

Published quarterly at $£ 15.00(\$ 50.00)$ per annum, post free

A Selection of Papers from Volume 13, Nos. 3 and 4, December 1975

C. $R$. Field: Climate and the food habits of ungulates on Galana Ranch

A. J. Hall-Martin, J. D. Skinner and J. M. Van Dyk: Reproduction in the giraffe in relation to some environmental factors

J. M. King, G. P. Kaingary, J. G. Colvin and B. R. Heath: Seasonal variation in water turnover by oryx and eland on the Galana Ranch Research Project

Dirk Kreulen: Wildebeest habitat selection on the Serengeti plains, Tanzania, in relation to calcium and lactation: a preliminary report

Larry D. Harris and Nicholas K. Fowler: Ecosystem analysis and simulation of the Mkomazi Reserve, Tanzania

M. Norton-Griffiths, D. Herlocker and Linda Pennycuick: The patterns of rainfall in the Serengeti Ecosystem, Tanzania

Subscriptions to either of these journals should be accompanied by the appropriate remittance and sent to Blackwell Scientific Publications Ltd., Osney Mead, Oxford OX2 OEL, England

\section{SWANS BIG GAME \& BIRDS SAFARIS}

\section{VISITING THESE NATIONAL PARKS \& GAME RESERVES IN EAST AFRICA}

Nairobi, Lake Naivasha, Lake Nakuru, Samburu, Isiolo, Tsavo, Amboseli, Lake Manyara, Ngorongoro, Serengeti, Mara and Aberdare in Kenya \& Tanzania.

\section{GUEST LECTURERS}

accompany each Safari. Their expert and personal knowledge of East Africa - its animals, birds, history, peoples and customs - provides an unrivalled opportunity, not only to view the ever decreasing wildlife in its natural habitat, but also to gain an insight into the problems of its preservation and the conservation of land needed by Africa's developing nations. A holiday that can open up new vistas of interest.

\section{DEPARTURES}

June 24; July 15; Aug 5, 26; Sept 16; Oct 7, 28; Nov 18; Dec 16

21 DAYS- $\$ 599$

12-page brochure available from:

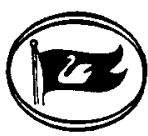




\title{
Journal of \\ Applied Ecology
}

Edited by

\author{
T.H. Coaker and R.W. Snaydon \\ Volume 12, Number 3, December 1975 (Contents)
}

D. A. Kendall and B. D. Smith. The pollinating efficiency of honeybee and bumblebee visits to field bean flowers (Vicea faba L.) M. I. Dyer. The effects of Red-winged Blackbirds (Agelaius phoeniceus L.) on biomass production of corn grains (Zea mays L.) D.J.W. Rose. Field development and quality changes in successive generations of Spodoptera exempta Wlk., the African armyworm Randall $F$. Johnson and Gary W. Barrett. Effects of diethylstilbestrol on feral house mouse (Mus musculus L.) population dynamics under experimental field conditions $\quad S . T$. Hassan. Effects of high temperature and soil moisture on survival of first-instar larvae of the scarab Anoplognathus porosus (Dalman) (Coleoptera) G. P. Vickerman and K. D. Sunderland. Arthropods in cereal crops : nocturnal activity, vertical distribution and aphid predation $\quad$ U. Gerson, E. Mescheloff and E. Dubitzki. The introduction of Neodusmetia sangwani (Rao) (Hymenoptera: Encyrtidae) into Israel for the control of the rhodesgrass scale, Anotonina graminis (Maskell) (Homoptera: Pseudococcidae) Jeffrey L. Lincer. DDEinduced eggshell-thinning in the American kestrel: a comparison of the field situation and laboratory results William W. Murdoch. Diversity, complexity, stability and pest control A. N. Baker and $R$. A. Dunning. Some effects of soil type and crop density on the activity and abundance of the epigeic fauna, particularly Carabidae, in sugar beet-fields $R$. $D$. Hughes (Ed.). Introduced dung beetles and Australian pasture ecosystems. Papers presented at a symposium during the meeting of the Australia and New Zealand Association for the Advancement of Science at Canberra in January 1975 J. M. Norman and P. G. Jarvis. Photosynthesis in Sitka spruce (Picea sitchensis (Bong.) Carr.). V. Radiation penetration theory and a test case $\quad R$. E. Neilson and P. G. Jarvis. Photosynthesis in Sitka spruce (Picea sitchensis (Bong.) (Carr.). VI. Response of stomata to temperature $M$. J. Liddle and $P$. Greig-Smith. A survey of tracks and paths in a sand dune ecosystem. I. Soils $M . J$. Liddle and $\boldsymbol{P}$. Greig-Smith. A survey of tracks and paths in a sand dune ecosystem. II. Vegetation J. Grace, D. C. Malcolm and Ian K. Bradbury. The effect of wind and humidity on leaf diffusive resistance in Sitka spruce seedlings $\quad$ G. C. Bate and Barbara V. Heelas. Studies on the nitrate nutrition of two indigenous Rhodesian grasses M. S. Davies. Physiological differences among populations of Anthoxanthum odoratum L. collected from the Park Grass Experiment, Rothamsted. IV. Response to potassium and magnesium R. S. Kinerson. Relationship between plant surface area and respiration in loblolly pine Ivan Valiela, John M. Teal and Warren J. Sass. Production and dynamics of salt marsh vegetation and the effects of experimental treatment with sewage slude. I. Biomass, production and species composition Reviews

The Journal of Applied Ecology is published three times a year subscription price $£ 30.00(\$ 105.00)$ per annum, post free. New subscriptions and requests for specimen copies should be addressed to Blackwell Scientific Publications Ltd, Osney Mead, Oxford OX2 0EL.

\section{Blackwell Scientific Publications}




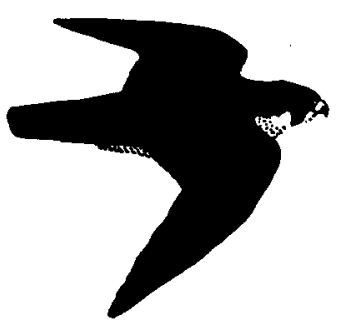

\section{The Hawk Trust}

The Hawk Trust was founded in 1969 to undertake research into all aspects of birds of prey: ecology, behaviour and disease problems; assist in the provision of voluntary wardens for breeding sites and undertake the experimental breeding of birds in captivity.

Members receive an Annual Report and periodic newsletters. Exhibitions, lectures and films are available by arrangement. An Open Day enables members to view the Hawk Trust's work at the end of the breeding season.

Subscriptions: Full Member $£ 4.00$; Family $£ 6.00$; Student $£ 2.00$

For further details apply:

The Secretary,

P.O. Box 1,

Hungerford,

Berks.

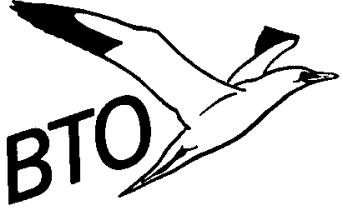

\section{BIRD STUDY}

The quarterly journal of the BTO where major topics of bird biology -ecology, population and distribution, behaviour, migration and ringing-are given full statistical and analytical discussion. For all whose interest is with birds and their reactions in an environment increasingly dominated by man.

Price $f 4$ p.a., or free to members of the BTO (details from the Administrator). Recent contributions have included:

Where have all the Whitethroats gone? by D. Winstanley, R. Spencer \& K. Williamson

The results of ringing auks in Britain and Ireland by C. J. Mead

The census of heronries by $C$. M. Reynolds

Local gull movements as a hazard to aircraft by D. R. Grant

Breeding of the Woodcock in Britain by R. Morgan and Monica Shorten

Food of the Barn Owl in Britain and Ireland by D. E. Glue

Ecological succession and bird-life at a newly excavated gravel-pit by B. S. Milne The breeding bird community of chalk grassland scrub in the Chiltern Hills by K. Williamson

Published by the British Trust for Ornithology, Beech Grove, Tring, Herts. (Tring 3461) 


\section{Application for Membership}

\section{The Fauna Preservation Society}

c/o The Zoological Society of London, Regent's Park, London NW1 4RY

Please enrol me as a member of the Society

Name (BLOCK LETTERS) Please state Mr/Mrs/Miss or title

\section{Address}

lenclose $f$ : :

being my subscription as a Life/Benefactor/Ordinary Member.

The minimum subscription for Ordinary Members is $£ 5$, US $\$ 12.50$, for Benefactors $£ 10$, US \$25, payable on January 1st. A Banker's Order saves time, expense and reminders. The value of any subscription is greatly increased if it is paid under a seven-year Deed of Covenant (UK standard-rate income taxpayers only) and this entails no extra cost whatever: write for Covenant forms to the Secretary.

Life membership fees:

Age: Under 41 , $£ 200$, US $\$ 485$; age $41-60, £ 150$, US $\$ 385$; age 61 and over, $£ 75$, US $\$ 185$.

\section{Banker's Order}

Bank

Address of Bank

Please pay for the Credit of The Fauna Preservation Society, Barclays Bank Ltd. Camden Town, London NW1, my subscription of $\{\ldots \ldots \ldots \ldots \ldots$ due on 1 st January 19 , and a similar amount on 1 st January each year until further notice. 